\title{
The bagworm, Amicta quadrangularis (Christoph), and its natural enemies in Northern Egypt (Lepidoptera: Psychidae)
}

\author{
Monir M. El Husseini ${ }^{* *}$ (D) and Salama I. Askar ${ }^{2}$
}

\begin{abstract}
The bagworm, Amicta quadrangularis (Christoph) (Lepidoptera: Psychidae), was found infesting the white broom, Retana raetam (Frossk.) (Fabales: Fabaceae), a flowering wild plant native to northern Africa, in the desert area of Northern Egypt. This study sheds the light on some biological, morphological, and behavioral aspects of this insect species. A survey of the natural enemies associated with the larval stage revealed insectivorous birds (29-33\%), a high percentage of parasitism by the ichneumonid, parasitoid species, Exeristes (Pimpla) roborator (Fab.) (Hymenoptera: Ichneumonidae) (8-11\%), and the tachinid, Exorista (=Tachina) larvarum L. (Diptera: Tachinidae) (14-21\%). The total percentage of attacking larvae by different natural enemies reached $(51-65 \%)$ at the area of study.
\end{abstract}

\section{Background}

The psychid bagworm, Amicta quadrangularis (Christoph) (Psyche quadrangularis Staudinger, 1874; Psyche quadrangularis var. nigrescens Staudinger, 1874), was first recorded in Egypt by Rebel (1901) and cited by Sobczyk (2011) in "The World Catalogue of Insects: Lepidoptera: Psychidae". Meanwhile, it was recorded by Simpson (2017) in Dahab, South Sinai, in the desert sand dunes on the white broom bush (Retama raetam), the flowering plant in the family Fabaceae native to Northern Africa. Its economic importance is known as an important factor in soil protection and stabilization against water erosion and wind aside from its use as a forage plant for desert livestock species like camels, goats, and sheep (Laudadio et al. 2009). Also, it offers a viable fuel source for desert nomads (Cheriti et al. 2009). From the pharmaceutical point of view, its roots are used to treat diarrhea and its leaves are for mild aching joints, back pain, and eye troubles (Said et al. 2002). A. quadrangularis was recorded and studied in some neighbor countries in the Middle East, i.e., in South Palestine, about ten miles south of Gaza (Flinders 1930), and in Israel

\footnotetext{
* Correspondence: monir.elhusseini@agr.cu.edu.eg;

monirelhusseini45@gmail.com

${ }^{1}$ Center of Biological Control, Faculty of Agriculture, Cairo University, Giza,

Egypt

Full list of author information is available at the end of the article
}

(Alon 1989). Nevertheless, its damage as a pest on trees or shrubs has not been mentioned in Egypt before. It could be due to its low population limited to the desert area in the country aside from the presence of different natural enemies that share in suppressing its population. On the other hand, it causes serious damage as a defoliator to agricultural and ornamental plants in other countries, e.g., in Turkey (Turkmen 1987) and in Jordan (Sobczyk 2011). The desert ecosystem is climatically known as the most inhospitable sand heath or desert. Accordingly, the larvae build such exceptionally characteristic bags and live inside, protected against the high-temperature variations of the area (Hättenschwiler and Alemansoor 2006).

In the present study, a reclaimed large desert land cultivated by apple orchard at Noubaria in Northern Egypt is surrounded by the desert, in which white broom $(R$. raetam) was located by chance and is widely distributed. The bagworm sacs of the pest were observed hanging on the branches of the white broom. Thus, samples of sacs were regularly collected in June/July for two successive years, 2017 and 2018, as an indicator of the presence of A. quadrangularis population and its associated natural enemies during this period, as an aim of this study. 


\section{Materials and methods}

The known typically square-shaped bags of $A$. quadrangularis larvae hanging from the branches of the white broom were handpicked. A number of 50 bags were collected weekly during July and August 2017 and 2018. Only the large bags (sacs) with mostly feeding larvae were sampled and transferred in paper bags to the laboratory for examination. Each sac was placed in $1 \times 3$ in. glass tube supplied daily with fresh plant parts (white broom) and covered with muslin fitted in place by a rubber band and kept under room temperature $\left(25-30^{\circ} \mathrm{C}\right)$ and about $60 \%$ R.H., until adult moth or parasitoid emergence. Measurements and numbers of male and female sacs were recorded for sex ratio as well as the numbers and species of emerged parasitoids. Also, molted head capsules of larvae inside the bags were calculated as an indicator to the number of larval instars.

\section{Results and discussion Habitat}

The bagworm, A. quadrangularis, is mainly known around the world from the sandy, desert-like areas with bushes and shrubs. Noubaria is located at Beheira governorate, Egypt, latitude $30^{\circ} 42^{\prime} 51^{\prime \prime}\left(30.7142^{\circ}\right)$ north, longitude $30^{\circ} 44^{\prime} 32.4^{\prime \prime}\left(30.7423^{\circ}\right)$, and east and elevation 9 $\mathrm{m}(30 \mathrm{ft})$. The annual rainfall if present varies between 100 to $200 \mathrm{~mm}$ only, which falls if present between December and February in 2- or 3-week downpours. The bags/sacs with feeding larvae of $A$. quadrangularis were found distributed on the local white broom plant, $R$. raetam, and not either on apple trees or other wild flora in the adjacent desert area.

\section{Larval sacs}

The hatched larvae start protecting themselves by cutting or collecting cylindrical tiny pieces from the branches of the white broom host plant and adhere them with silk produced by their salivary glands. The larva arranges these pieces in a square like a log shelter. As the larva grows, it extends the front opening of the case by adding longer material to the four sides of the sac to widen it, fitting its grown body (Fig. 1); this observation is in agreement with that of Kraemer (1949). An opening hole is formed at the back of the sac through which it excretes waste, and this agrees with the description of Kristensen (1989). Because the sac is built from the parts of the white broom the larvae feed on, the sac's appearance provides its inhabitant larva a perfect camouflage, leaving it difficult to be spotted by the naked eye on the host plant. The larvae move around on the host plant using its thoracic legs, carrying their sacs on the abdomen behind, using the crouches of their abdominal legs.

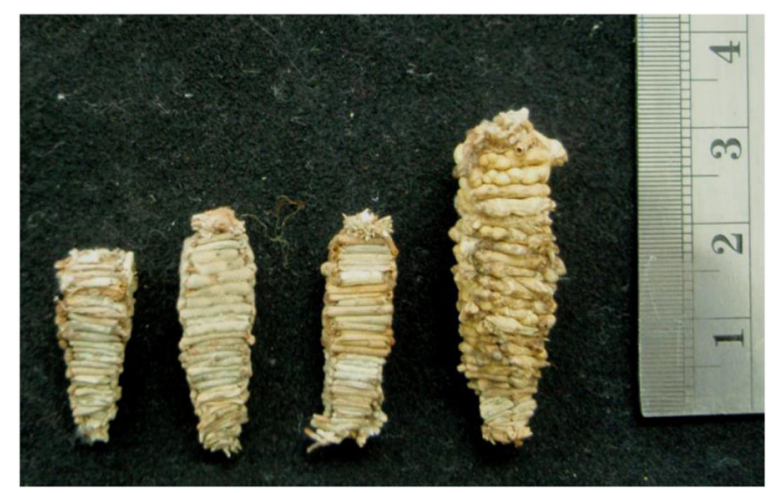

Fig. 1 Sacs built from white broom plant parts by larvae of $A$. quadrangularis (right: female sac; others: male sacs)

The sacs of the females ( 0.7 in width and $3.7 \mathrm{~cm}$ long) are larger than those of the males (0.6 in width and 2.5 $\mathrm{cm}$ long) (Fig. 1). Flinders (1930) measured the mean size of the pieces the larva used to build its sac/bag beginning at $0.2 \mathrm{in}$., widening to 0.32 , and tapering to 0.27 . $\mathrm{He}$ added that the lengths of stem used on different sides are distinguished by four directions of the cross strokes. Counting the head capsules inside each sac, it proved that $A$. quadrangularis larval stage passed five larval instars for both male and female. Reaching adult stage, female moth remains inside its sac because it is wingless, but the male moth abandons the sac, leaving the anterior part of the pupal exuvium protruding from the sac (Fig. 2).

The male interocular distance between compound eyes measures less than the height with a distance of 1.3 times the eye diameter. Its abdomen is dark, and its thorax is with some long silver hairs of the head. The

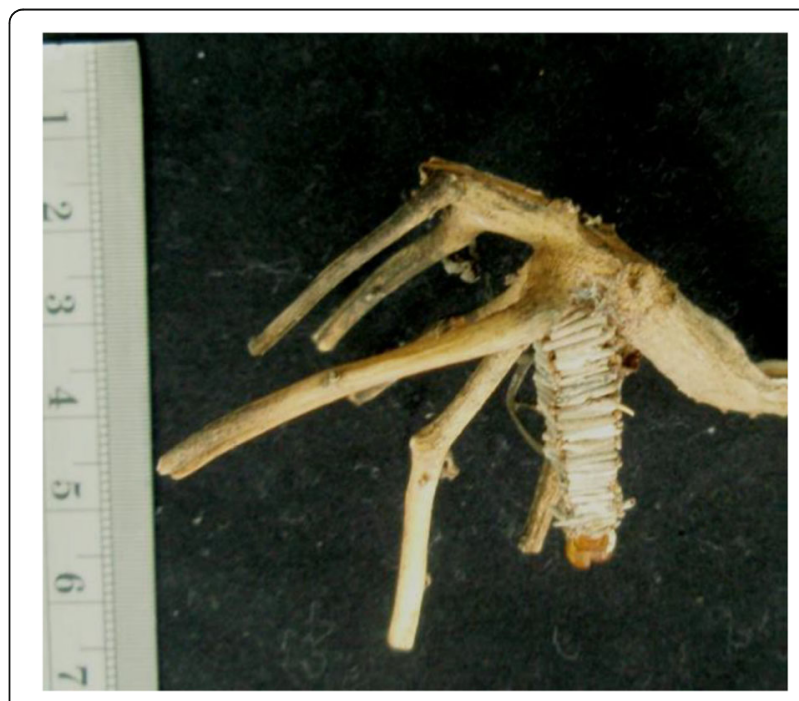

Fig. 2 Sac of male moth after adult emergence showing the tip of pupal exuvium visible 
male wing expanse reached $23 \mathrm{~mm}$ on the average. Its forewing anal area is with wide, short scales, class $3-5$ mostly with two tips. The tegument of the genitalia is rounded. These characteristics are the same that provided by Hättenschwiler and Alemansoor (2006). The male moths emerge from their sacs in July/August and fly searching for females. The emerged female moths remain inside their sacs producing their sex pheromone to attract the males for copulation. Providing a male moth into a chimney glass cage containing a female inside its sac, the female stayed motionless inside its sac while the male extended its abdomen into the female's sac for mating. The mating season extends from mid-August to mid-September. After mating with more than one female, the male died soon. The female lays between 1000 and 1500 eggs inside the sac and dies also inside it. It seems that the hatched young larvae feed first on the corpus of the dead female as protein source before leaving the sac to feed on the host plant and build their own sacs.

\section{Sex ratio}

Out of 400 collected sacs, only 210 adult moths emerged from the 49 adult males, forming a sex ratio of 1:4.2 (male to female).

\section{Associated natural enemies}

Through weekly random sampling of 50 sacs during July and August, the natural enemies associated with larval sacs of A. quadrangularis were recorded on the spot in the field by opening non-damaged large sacs with fine scissors (Table 1). Parasitoids were recorded on the larvae inside the sacs. It was very easy to differentiate between parasitism with Hymenoptera, i.e., Exeristes (Pimpla) roborator (Fab.) (Fam. Ichneumonidae), and those of Diptera, i.e., Exoristes (=Tachina) larvarum L.) (Fam. Tachinidae) where pupae or puparia of the fly are present in the sac. Parasitoid larvae and their parasitized host larvae were transferred to the laboratory and kept individually in glass tubes $(0.5 \times 2$ in. $)$ covered with cotton plug until adult parasitoids emergence. Parasitoids were identified by the first author at the Centre of Biological Control, Faculty of Agriculture, at Cairo University, Egypt. The empty and partially destroyed sacs were considered preyed by insectivorous birds, seen in action at the study area, attacking them on the plants where no

Table 1 Absolute figures of the in the field-associated natural enemies (\%) among larval sacs $(n=400)$ of $A$. quadrangularis

\begin{tabular}{lllll}
\hline Year & Birds \% & Tachinidae \% & Ichneumonidae \% & Total \\
\hline 2017 & 33 & 11 & 21 & $65 \%$ \\
2018 & 29 & 8 & 14 & $51 \%$ \\
\hline
\end{tabular}

other climbing bioagents were observed on the white broom shrubs.

Insectivorous birds preyed on (33 and 29\%) of the sampled larval sacs in 2017 and 2018, respectively. The tachinid parasitoid recorded (11 and 8\%) in the same years, respectively. The ichneumonid parasitoid reached a level of (21 and 14\%) parasitism in the two successive years, respectively. In general, the correspondent total percentage of the attacked larval sacs by all recorded natural enemies (the birds and the parasitoids) was (65 and 51\%) for the years 2017 and 2018, respectively.

Taking into consideration that a female of A. quadrangularis produces about 1500 eggs, it could be assumed that this insect might appear in a high population. But such a high percentage of natural enemies could clear the suppressed population of this insect in the area. In Iran, Hättenschwiler and Alemansoor (2006) recorded also a high percentage of attacks by different natural enemies (spiders, Torymidae, Chalcididae, and Tachinidae) on the larvae of the psychid Amicta sericata reaching (56.65 and 63.6\%) in two samples collected in 2005.

\section{Acknowledgements}

The authors thank and highly appreciate the cooperation of orchard owners in Nubaria area for allowing us sampling the material from and around their fields.

\section{Funding}

This work was not supported by any funding body, but personally financed.

\section{Availability of data and materials}

All data are available at the article and the materials used in this work are of high transparency and grade.

\section{Authors' contributions}

Both authors shared in collecting and inspecting the research material and specimens and recording the results. MMEH had written the manuscript which was approved by SIA. Both authors read and approved the final manuscript.

Ethics approval and consent to participate

We agree to all concerned regulations

Consent for publication

We agree to publish this scientific paper at the EJBPC

\section{Competing interests}

The authors declare that they have no competing interests.

\section{Publisher's Note}

Springer Nature remains neutral with regard to jurisdictional claims in published maps and institutional affiliations.

\section{Author details}

${ }^{1}$ Center of Biological Control, Faculty of Agriculture, Cairo University, Giza, Egypt. ${ }^{2}$ Plant Protection Department, Faculty of Agriculture, Damanhour University, Damanhur, Egypt. 
Received: 11 November 2018 Accepted: 28 March 2019

Published online: 14 May 2019

\section{References}

Alon A (1989) Jehoshua Kugler, ed. Amicta quadrangularis. Plants and animals of the land of Israel (in Hebrew). 3. Ministry of Defense, p 260 ISBN 965-050070-7

Cheriti A, Talhi MF, Belboukhari N, Taleb S, Roussel C (2009) Removal of copper from aqueous solution by Retama raetam Forssk. Growing in Algerian Sahara. Desalin Water Treat 10:317-320

Flinders P (1930) The accuracy of a moth. Nature 125:928-928. https://doi.org/10. 1038/125928c0

Hättenschwiler P, Alemansoor H (2006) A new species of Amicta Heylaerts, 1881 from the south of Iran (Psychidae). Nota Lepid 29(1/2):79-87

Kraemer GD (1949) Beiträge zur Biologie von Amicta quadranqularis Heyl. (Lep Psychidae). Zeitschrift der Wiener Entomologischen Gesellschaft 84:160-164

Kristensen NP (1989) Handbuch der Zoologie, Bd 4: Arthropoda: Insecta. Publisher: Walter De Grueyter GmbH \& Co, Berlin

Laudadio V, Tufarelli V, Dario M, Hammadi M, Seddik MM, Lacalandra GM, Dario C (2009) Chemical and nutritional characteristics of halophytes plants used by camels in Southern Tunisia. Trop Anim Health Prod 41:209-215

Rebel H (1901) Neue palaeartischen Tineen. Deutsche entomologische Zeitschrift, Iris 13(2):161-188

Said O, Khalil K, Fulder S, Azaizeh H (2002) Ethno-pharmacological survey of medicinal herbs in Israel, the Golan Heights and the West Bank region. J Ethnopharmacol 83:251-265

Simpson, Bernadette (2017). http://www.bernadettesimpson.com. Accessed Sept 2018

Sobczyk T (2011) World Catalogue of Insects, (Psychidae:Lepidoptera, 10: 1: 467), in Matthias Nuss (ed.), Apollo Books Aps, Stenstrup, Denmark

Staudinger O (1874) Einige neue Lepidopteren des europäischen Faunengebietes. Stettiner Entomologische Zeitung 35(1-3):87-98

Turkmen S (1987) A new pest of legumes (Amicta oberthuri Hey.) (Lepidoptera: Psychidae) in southeast Anatolia. Turkiye I Entomoloji Kongresi Bildirileri, 1316 Ekim, Ege Universitesi, Bornovo, Izmir, pp 239-248

\section{Submit your manuscript to a SpringerOpen ${ }^{\circ}$ journal and benefit from:}

- Convenient online submission

- Rigorous peer review

- Open access: articles freely available online

- High visibility within the field

- Retaining the copyright to your article

Submit your next manuscript at $\boldsymbol{\nabla}$ springeropen.com 